University of Nebraska - Lincoln

DigitalCommons@University of Nebraska - Lincoln

\title{
Efficacy of Methoprene for Control of Five Species of Psocids (Psocoptera) on Wheat, Rice, and Maize
}

Christos G. Athanassiou

University of Thessaly, athanassiou@agr.uth.gr

Frank H. Arthur

USDA-ARS, frank.arthur@ars.usda.gov

James E. Throne

USDA-ARS, Manhattan, KS, james.throne@ars.usda.gov

Follow this and additional works at: https://digitalcommons.unl.edu/usdaarsfacpub

Athanassiou, Christos G.; Arthur, Frank H.; and Throne, James E., "Efficacy of Methoprene for Control of Five Species of Psocids (Psocoptera) on Wheat, Rice, and Maize" (2010). Publications from USDA-ARS / UNL Faculty. 2046.

https://digitalcommons.unl.edu/usdaarsfacpub/2046

This Article is brought to you for free and open access by the U.S. Department of Agriculture: Agricultural Research Service, Lincoln, Nebraska at DigitalCommons@University of Nebraska - Lincoln. It has been accepted for inclusion in Publications from USDA-ARS / UNL Faculty by an authorized administrator of DigitalCommons@University of Nebraska - Lincoln. 


\title{
Efficacy of Methoprene for Control of Five Species of Psocids (Psocoptera) on Wheat, Rice, and Maize
}

\author{
CHRISTOS G. ATHANASSIOU, ${ }^{1,2 *}$ FRANK H. ARTHUR, ${ }^{2}$ AND JAMES E. THRONE ${ }^{2}$
}

\begin{abstract}
${ }^{1}$ Laboratory of Entomology and Agricultural Zoology, Department of Agriculture, Crop Production and Rural Environment, University of Thessaly, Phytokou Str., 38443, N. Ionia, Magnisia, Greece; and ${ }^{2}$ U.S. Department of Agriculture, Agricultural Research Service, Center for Grain and Animal Health Research, 1515 College Avenue, Manhattan, Kansas 66502, USA
\end{abstract}

MS 10-203: Received 11 May 2010/Accepted 30 August 2010

\begin{abstract}
The insect growth regulator methoprene was evaluated for control of Liposcelis bostrychophila Badonnel, Liposcelis decolor (Pearman), Liposcelis entomophila (Enderlein), Liposcelis paeta Pearman (Psocoptera: Liposcelididae), and Lepinotus reticulatus Enderlein (Trogiidae) at application rates of 1,5, and $10 \mathrm{ppm}$ on maize, wheat, and rice. Methoprene did not completely suppress progeny production during the 40-day test period, but did cause a significant reduction in adult progeny in all psocid species at the application rates of 5 and $10 \mathrm{ppm}$. At $1 \mathrm{ppm}$, numbers of adults were reduced for all species on wheat and maize, but only for L. paeta on rice. Nevertheless, the numbers of nymphs present after 40 days generally were not reduced, relative to the controls. Methoprene applied at rates of 1 to $10 \mathrm{ppm}$ to stored grain would not provide adequate control of psocids.
\end{abstract}

Psocoptera (psocids) have become pests of stored products in Australia, China, and the United States during the last two decades $(20,29)$. Psocids can feed on grain kernels and cause quality loss; they can also be cause for rejection of export grain and a health hazard (17). Many psocid species are tolerant to contact insecticides, and they can survive exposure on grains treated with concentrations of insecticides that will control other insect species in stored grains. For example, Nayak et al. (22) reported that Liposcelis bostrychophila Badonnel, Liposcelis entomophila (Enderlein), and Liposcelis paeta Pearman (Psocoptera: Liposcelididae) were tolerant to the pyrethroids deltamethrin and bioresmethrin and the carbamate carbaryl. The latter two species were also tolerant to the organophosphorus insecticides chlorpyriphos-methyl, pirimiphos-methyl, and fenitrothion. Daglish et al. (12) reported that L. entomophila was tolerant to bifenthrin, while spinosad was only moderately effective against $L$. bostrychophila, L. paeta, and Liposcelis decolor (Pearman) (23).

The use of insect growth regulators (IGRs) as grain protectants has certain advantages over traditional neurotoxic insecticides, including low mammalian toxicity, residual persistence, and reduced risks to applicators $(1,7$, 9-11, 13). Methoprene is currently the only IGR that is registered as a grain protectant in the United States at the label rates of $1,2.5$, and $5 \mathrm{ppm}$. It is a juvenile hormone analogue, and it can confer egg toxicity as well as disruption of normal development of the immature stages. Several studies indicate that methoprene, alone or in combination

\footnotetext{
* Author for correspondence. Tel: + 30-2421093195; Fax: + 30-2421093195; E-mail: athanassiou@agr.uth.gr.
}

with other reduced-risk insecticides, can control stored-grain insects, including those populations that are resistant to organophosphorus insecticides $(4-11,19,21,24)$.

There are few reports in the scientific literature regarding efficacy of IGRs against psocids. Bucci (3) evaluated both methoprene and fenoxycarb against $L$. bostrychophila by mixing different doses of these insecticides in the psocid rearing media. The author found that methoprene reduced the numbers of adults produced, but not the numbers of nymphs. Although the tested rates were as high as $190 \mathrm{ppm}$, complete progeny production was not achieved but adult fertility and egg hatch were reduced. Nayak et al. $(21,22)$ obtained similar results on efficacy of methoprene at $1 \mathrm{ppm}$ on wheat, which is the registered rate in Australia, against L. bostrychophila, L. decolor, $L$. entomophila, and L. paeta, with little to no adult mortality and little progeny suppression. However, there are no data available on methoprene for control of psocids at the higher registered rates in the United States, such as 2.5 and 5 ppm, and on other commodities including rice and maize. In addition, previous studies have shown significant variation in efficacy of grain protectants on different commodities $(2$, 16, 27). The objective of our study was to evaluate efficacy of methoprene at different application rates on wheat, rice, and maize for control of the stored-grain psocids $L$. bostrychophila, L. entomophila, L. paeta, L. decolor, and Lepinotus reticulatus Enderlein (Psocoptera: Trogiidae). We tested the label rates of 1 and $5 \mathrm{ppm}$; we also tested twice the label rate of $10 \mathrm{ppm}$ to determine whether this rate would have greater efficacy for psocids. Label rates for grain insecticides are based on rates required to kill beetle pests, and psocids often are not susceptible at these rates. 
TABLE 1. Number of adults and nymphs of Liposcelis bostrychophila per vial 40 days after the introduction of 10 female parental individuals on untreated commodities $(0 \mathrm{ppm})$ or commodities treated with methoprene at three dose rates ${ }^{a}$

\begin{tabular}{|c|c|c|c|c|c|c|}
\hline Stage & Dose (ppm) & Wheat & Rice & Maize & $F$ value & $P$ value \\
\hline \multirow[t]{6}{*}{ Adult $^{b}$} & 0 & $102.6 \pm 18.0 \mathrm{a}^{c}$ & $75.8 \pm 13.0 \mathrm{a}$ & $48.2 \pm 14.6 \mathrm{a}$ & 3.1 & 0.06 \\
\hline & 1 & $6.3 \pm 1.4 \mathrm{~A} \mathrm{~b}$ & $66.7 \pm 15.3$ в а & $4.2 \pm 0.9 \mathrm{~A} \mathrm{~b}$ & 15.9 & $<0.01$ \\
\hline & 5 & $4.2 \pm 0.7 \mathrm{~b}$ & $5.8 \pm 1.4 \mathrm{~b}$ & $3.1 \pm 0.8 \mathrm{~b}$ & 2.2 & 0.14 \\
\hline & 10 & $4.5 \pm 0.5 b$ & $5.8 \pm 0.9 \mathrm{~b}$ & $2.8 \pm 0.7 \mathrm{~b}$ & 3.3 & 0.06 \\
\hline & $F$ value & 29.1 & 14.1 & 9.3 & & \\
\hline & $P$ value & $<0.01$ & $<0.01$ & $<0.01$ & & \\
\hline \multirow[t]{6}{*}{ Nymph $^{d}$} & 0 & $48.0 \pm 11.4 \mathrm{~A}$ & $21.6 \pm 5.8$ в & $9.0 \pm 1.7$ в & 7.1 & $<0.01$ \\
\hline & 1 & $39.1 \pm 13.9$ & $18.2 \pm 5.5$ & $10.0 \pm 2.4$ & 2.9 & 0.07 \\
\hline & 5 & $34.9 \pm 6.7 \mathrm{~A}$ & $26.7 \pm 6.7 \mathrm{~A}$ & $5.8 \pm 1.7$ в & 6.3 & $<0.01$ \\
\hline & 10 & $38.2 \pm 7.7 \mathrm{~A}$ & $26.3 \pm 3.6 \mathrm{~A}$ & $3.5 \pm 1.4$ в & 15.6 & $<0.01$ \\
\hline & $F$ value & 0.3 & 0.5 & 2.5 & & \\
\hline & $P$ value & 0.83 & 0.65 & 0.07 & & \\
\hline
\end{tabular}

${ }^{a}$ Values are means $\pm \mathrm{SE}$.

${ }^{b}$ Two-way ANOVA results for adults: dose, $\mathrm{df}=3,96, F=42.6$; commodity, $\mathrm{df}=2,96, F=7.4$; dose $\times$ commodity, $\mathrm{df}=6,96$, $F=5.9$; in all cases $P<0.01$.

${ }^{c}$ Within each row, means followed by the same uppercase letter(s) are not significantly different; within each life stage and column, means followed by the same lowercase letter(s) are not significantly different; where no letters exist, no significant differences were noted; in all cases for rows $\mathrm{df}=2,24$, for columns $\mathrm{df}=3,32$; HSD test at 0.5 .

${ }^{d}$ Two-way ANOVA results for nymphs: dose, $\mathrm{df}=3,96, F=0.2, P=0.88$; commodity, $\mathrm{df}=2,96, F=23.1, P<0.01$; dose $\times$ commodity, df $=6,96, F=0.5, P=0.81$.

\section{MATERIALS AND METHODS}

Commodities and formulation. Untreated, clean, and infestation-free wheat (Triticum aestivum L., a mixture of the var. Fuller and Santa Fe), rice (Oryza sativa L., var. Francis), and maize (Zea mays L., hybrid Golden Harvest H-8713) were used in the tests. The moisture contents of the grains were adjusted to $13.5 \%$ before the beginning of the experiments. The methoprene formulation used in the tests was Diacon II (Wellmark International, Schaumburg, IL), a formulation that contains $33.6 \%$ active ingredient of $(S)$-methoprene.

Insects. Five psocid species were used in the tests, $L$. bostrychophila, L. decolor, L. entomophila, L. paeta, and L. reticulatus. All species were reared on a mixture of $97 \%$ cracked wheat kernels, $2 \%$ Rice Krispies, and $1 \%$ brewer's yeast at $30^{\circ} \mathrm{C}$ and $70 \%$ relative humidity, as suggested by Opit and Throne (25). Adult females, less than 4 weeks old, were collected as described by Opit and Throne (25). Based on this method, adult females are allowed to oviposit in dishes containing colored diet; the females are removed in order to obtain progeny of known age.

Bioassays. Individual lots of $1.6 \mathrm{~kg}$ of wheat, rice, and maize were divided into sublots of $400 \mathrm{~g}$ each (four sublots for each commodity). Separate insecticide solutions of 1, 5, and $10 \mathrm{ppm}$ were prepared to treat each commodity in accordance with the directions specified on the insecticide label, to deliver the appropriate volume ratio for each commodity. In addition to the three insecticide rates, a fourth treatment consisting of an untreated control (sprayed with water only) was used. The insecticide solutions and the untreated controls were sprayed with an artists' airbrush (Badger 100, Badger Air-Brush Company, Franklin Park, IL). After the sublots of each commodity were sprayed, they were placed in 0.47-liter glass jars and hand tumbled for $30 \mathrm{~s}$. From each jar, three aliquot samples of $10 \mathrm{~g}$ each were removed and placed in cylindrical plastic vials ( $3 \mathrm{~cm}$ in diameter, $8 \mathrm{~cm}$ in height). Ten females of $L$. bostrychophila were placed in each vial. The same procedure was followed for the remaining four psocid species, by taking new aliquot samples from the treated lots. The vials had a plastic lid with a hole in the center covered with fine mesh. The internal neck of the vials was covered by Fluon (Northern Products, Woonsocket, RI) to prevent psocids from escaping. All vials were then placed in black plastic boxes with saturated salt solutions of sodium chloride to maintain the relative humidity level at $75 \%$, as suggested by Opit and Throne (25), and the boxes were placed in incubators set at $27.5^{\circ} \mathrm{C}$ and $75 \%$ relative humidity. The vials were opened after 40 days, and the numbers of live individuals were recorded separately for adults and nymphs. The entire procedure was replicated two times more by preparing new $1.6-\mathrm{kg}$ lots each time, which gave a total of nine vials for each species-commodity-dose combination.

Data analysis. Data were analyzed separately for each species and life stage (adults or nymphs) by using a two-way analysis of variance (ANOVA), with commodity and application rate as main effects. Before the analysis, the data were arcsine transformed to normalize the variances. Progeny production in the control vials was also included in the analysis ( 0 ppm rate). Means were separated by using the Tukey-Kramer honestly significant difference (HSD) test at 0.05 .

\section{RESULTS}

Adults. Interaction between main effects commodity and dose of methoprene were significant for all species (Tables 1 through 5), so one-way ANOVAs were used to determine significance of main effects. Numbers of adults present after 40 days were reduced, relative to the controls, for all species on all crops at 5- and 10-ppm application rates of methoprene. However, complete suppression was never achieved. At 1 ppm, numbers of adults were reduced for all species on wheat and maize, but not on rice, except for L. paeta.

Numbers of adults present on treated maize and wheat after 40 days did not differ with methoprene application 
TABLE 2. Number of adults and nymphs of Liposcelis entomophila per vial 40 days after the introduction of 10 female parental individuals on untreated commodities $(0 \mathrm{ppm})$ or commodities treated with methoprene at three dose rates ${ }^{a}$

\begin{tabular}{|c|c|c|c|c|c|c|}
\hline Stage & Dose (ppm) & Wheat & Rice & Maize & $F$ value & $P$ value \\
\hline \multirow[t]{6}{*}{ Adults $^{b}$} & 0 & $155.3 \pm 10.8 \mathrm{~A} \mathrm{a}^{c}$ & $132.1 \pm 10.0 \mathrm{~A} \mathrm{a}$ & $66.9 \pm 14.6$ в а & 14.7 & $<0.01$ \\
\hline & 1 & $40.0 \pm 15.8 \mathrm{~A} \mathrm{~b}$ & $97.0 \pm 15.4 \mathrm{в} \mathrm{а}$ & $17.8 \pm 9.6 \mathrm{~A} \mathrm{~b}$ & 8.7 & $<0.01$ \\
\hline & 5 & $8.3 \pm 0.8 \mathrm{~A} \mathrm{c}$ & $15.2 \pm 2.7$ в & $6.1 \pm 0.6 \mathrm{~A} \mathrm{~b}$ & 8.2 & $<0.01$ \\
\hline & 10 & $7.5 \pm 1.1 \mathrm{c}$ & $8.8 \pm 0.5 \mathrm{~b}$ & $7.2 \pm 0.5 \mathrm{~b}$ & 1.2 & 0.33 \\
\hline & $F$ value & 53.2 & $\overline{43} .2$ & 10.8 & & \\
\hline & $P$ value & $<0.01$ & $<0.01$ & $<0.01$ & & \\
\hline \multirow[t]{6}{*}{ Nymphs $^{d}$} & 0 & $65.6 \pm 10.3 \mathrm{~A}$ & $42.0 \pm 5.9$ А $\mathrm{B}$ & $21.8 \pm 5.1$ в аb & 8.6 & $<0.01$ \\
\hline & 1 & $80.0 \pm 8.6 \mathrm{~A}$ & $44.1 \pm 4.8$ в & $26.7 \pm 3.2$ в а & 20.8 & $<0.01$ \\
\hline & 5 & $75.8 \pm 8.2 \mathrm{~A}$ & $52.8 \pm 6.6$ в & $10.4 \pm 4.0 \mathrm{c} \mathrm{b}$ & 26.1 & $<0.01$ \\
\hline & 10 & $61.8 \pm 11.8 \mathrm{~A}$ & $58.8 \pm 5.7 \mathrm{~A}$ & $9.8 \pm 3.9$ в b & 13.7 & $<0.01$ \\
\hline & $F$ value & 0.7 & 1.8 & 4.2 & & \\
\hline & $P$ value & 0.53 & 0.16 & 0.01 & & \\
\hline
\end{tabular}

${ }^{a}$ Values are means $\pm \mathrm{SE}$.

${ }^{b}$ Two-way ANOVA results for adults: dose, $\mathrm{df}=3,96, F=94.1$; commodity, $\mathrm{df}=2,96, F=18.9$; dose $\times$ commodity, $\mathrm{df}=6,96, F=$ 8.6; in all cases $P<0.01$.

${ }^{c}$ Within each row, means followed by the same uppercase letter(s) are not significantly different; within each life stage and column, means followed by the same lowercase letter(s) are not significantly different; where no letters exist, no significant differences were noted; in all cases for rows $\mathrm{df}=2,24$, for columns $\mathrm{df}=3,32$; HSD test at 0.5 .

${ }^{d}$ Two-way ANOVA results for nymphs: dose, $\mathrm{df}=3,96, F=0.7, P=0.57$; commodity, $\mathrm{df}=2,96, F=59.5, P<0.01$; dose $\times$ commodity, df $=6,96, F=1.7, P=0.11$.

rate except for L. entomophila on wheat; significantly fewer adult progeny were present in the 5- and 10-ppm treatments than at $1 \mathrm{ppm}$. On rice, numbers of adults were always greater in the 1-ppm treatment than on rice treated with higher doses of methoprene. Reductions in adult progeny numbers exceeded $90 \%$ in all crops for L. bostrychophila and L. entomophila, and exceeded $81 \%$ for the other species. Reductions in L. bostrychophila adult progeny numbers were 95.9, 92.3, and $94.2 \%$ for wheat, rice, and maize, respectively; 95.2, 93.3, and $90.9 \%$ for $L$. entomophila; 96.0, 93.2, and 87.1\% for L. reticulatus; 86.2, 85.7, and $81.7 \%$ for L. paeta; and 94.5, 82.0, and $92.2 \%$ for $L$. decolor. Thus, L. paeta adult progeny numbers were the least impacted by methoprene application, and $L$. bostrychophila and L. entomophila were the most impacted.

Nymphs. Generally, the numbers of nymphs present in treated grain after 40 days were not reduced, relative to the controls, with some exceptions (Tables 1 through 5).

TABLE 3. Number of adults and nymphs of Lepinotus reticulatus per vial 40 days after the introduction of 10 female parental individuals on untreated commodities $\left(0\right.$ ppm) or commodities treated with methoprene at three dose rates ${ }^{a}$

\begin{tabular}{|c|c|c|c|c|c|c|}
\hline Stage & Dose (ppm) & Wheat & Rice & Maize & $F$ value & $P$ value \\
\hline \multirow[t]{6}{*}{ Adults $^{b}$} & 0 & $151.2 \pm 7.2 \mathrm{~A} \mathrm{a}^{c}$ & $87.8 \pm 15.4$ в а & $45.1 \pm 5.7 \mathrm{c} \mathrm{a}$ & 26.6 & $<0.01$ \\
\hline & 1 & $14.7 \pm 5.0 \mathrm{~A} \mathrm{~b}$ & $93.1 \pm 11.5$ в а & $12.3 \pm 5.5 \mathrm{~A} \mathrm{~b}$ & 33.7 & $<0.01$ \\
\hline & 5 & $6.9 \pm 1.8 \mathrm{~b}$ & $11.0 \pm 1.8 \mathrm{~b}$ & $5.8 \pm 0.9 \mathrm{~b}$ & 3.1 & 0.06 \\
\hline & 10 & $6.1 \pm 0.8 \mathrm{~b}$ & $6.0 \pm 1.3 \mathrm{~b}$ & $6.1 \pm 1.2 \mathrm{~b}$ & 0.1 & 0.99 \\
\hline & $F$ value & 251.8 & 23.9 & 21.7 & & \\
\hline & $P$ value & $<0.01$ & $<0.01$ & $<0.01$ & & \\
\hline \multirow[t]{6}{*}{ Nymphs $^{d}$} & 0 & $55.8 \pm 7.0 \mathrm{~A}$ & $28.8 \pm 4.6$ в а & $16.7 \pm 2.8$ в аb & 15.4 & $<0.01$ \\
\hline & 1 & $50.8 \pm 9.5 \mathrm{~A}$ & $43.5 \pm 3.8 \mathrm{~A} \mathrm{ab}$ & $27.0 \pm 4.7$ в а & 3.5 & 0.04 \\
\hline & 5 & $56.3 \pm 8.3 \mathrm{~A}$ & $51.3 \pm 5.2 \mathrm{~A} \mathrm{~b}$ & $18.2 \pm 6.6$ в аb & 10.5 & $<0.01$ \\
\hline & 10 & $44.3 \pm 6.0 \mathrm{~A}$ & $35.7 \pm 5.3 \mathrm{~A} \mathrm{ab}$ & $7.8 \pm 2.5$ в $\mathrm{b}$ & 15.5 & $<0.01$ \\
\hline & $F$ value & 0.5 & 4.2 & 4.0 & & \\
\hline & $P$ value & 0.68 & 0.01 & 0.02 & & \\
\hline
\end{tabular}

\footnotetext{
${ }^{a}$ Values are means \pm SE.

${ }^{b}$ Two-way ANOVA results for adults: dose, $\mathrm{df}=3,96, F=118.6$; commodity, $\mathrm{df}=2,96, F=27.7$; dose $\times$ commodity, $\mathrm{df}=6,96, F$ $=28.9$; in all cases $P<0.01$.

${ }^{c}$ Within each row, means followed by the same uppercase letter(s) are not significantly different; within each life stage and column, means followed by the same lowercase letter(s) are not significantly different; where no letters exist, no significant differences were noted; in all cases for rows $\mathrm{df}=2,24$, for columns $\mathrm{df}=3,32$; HSD test at 0.5 .

${ }^{d}$ Two-way ANOVA results for nymphs: dose, $\mathrm{df}=3,96, F=3.2, P=0.03$; commodity, $\mathrm{df}=2,96, F=36.8, P<0.01$; dose $\times$ commodity, $\mathrm{df}=6,96, F=1.2, P=0.28$.
} 
TABLE 4. Number of adults and nymphs of Liposcelis paeta per vial 40 days after the introduction of 10 female parental individuals on untreated commodities $\left(0\right.$ ppm) or commodities treated with methoprene at three dose rates ${ }^{a}$

\begin{tabular}{|c|c|c|c|c|c|c|}
\hline Stage & Dose (ppm) & Wheat & Rice & Maize & $F$ value & $P$ value \\
\hline \multirow[t]{6}{*}{ Adults ${ }^{b}$} & 0 & $53.7 \pm 7.1 \mathrm{~A} \mathrm{a}^{c}$ & $41.9 \pm 4.7 \mathrm{~A} \mathrm{a}$ & $19.7 \pm 3.1$ в а & 10.8 & $<0.01$ \\
\hline & 1 & $8.6 \pm 0.9 \mathrm{~A} \mathrm{~b}$ & $26.3 \pm 3.2$ в & $6.0 \pm 0.9 \mathrm{~A} \mathrm{~b}$ & 30.7 & $<0.01$ \\
\hline & 5 & $7.4 \pm 0.8 b$ & $6.0 \pm 1.3 \mathrm{c}$ & $6.9 \pm 0.9 \mathrm{~b}$ & 0.5 & 0.63 \\
\hline & 10 & $7.9 \pm 1.4 \mathrm{~A} \mathrm{~b}$ & $7.1 \pm 0.9$ А c & $3.6 \pm 0.9$ в $\mathrm{b}$ & 4.4 & 0.02 \\
\hline & $F$ value & 38.4 & 33.1 & 17.2 & & \\
\hline & $P$ value & $<0.01$ & $<0.01$ & $<0.01$ & & \\
\hline \multirow[t]{6}{*}{ Nymphs $^{d}$} & 0 & $35.9 \pm 5.3 \mathrm{~A}$ & $39.4 \pm 3.4 \mathrm{~A} \mathrm{a}$ & $14.8 \pm 2.8$ в & 11.0 & $<0.01$ \\
\hline & 1 & $40.8 \pm 5.9 \mathrm{~A}$ & $46.4 \pm 3.7 \mathrm{~A} \mathrm{a}$ & $11.6 \pm 2.8$ в & 18.4 & $<0.01$ \\
\hline & 5 & $29.4 \pm 4.0 \mathrm{~A}$ & $24.4 \pm 4.2 \mathrm{~A} \mathrm{~b}$ & $11.9 \pm 2.2$ в & 6.4 & $<0.01$ \\
\hline & 10 & $36.6 \pm 8.1 \mathrm{~A}$ & $17.7 \pm 2.5$ в & $5.2 \pm 0.7 \mathrm{C}$ & 9.9 & $<0.01$ \\
\hline & $F$ value & 0.6 & 14.2 & 2.6 & & \\
\hline & $P$ value & 0.62 & $<0.01$ & 0.07 & & \\
\hline
\end{tabular}

${ }^{a}$ Values are means \pm SE.

${ }^{b}$ Two-way ANOVA results for adults: dose, $\mathrm{df}=3,96, F=81.2$; commodity, $\mathrm{df}=2,96, F=18.5$; dose $\times$ commodity, $\mathrm{df}=6,96, F=$ 10.6 ; in all cases $P<0.01$.

${ }^{c}$ Within each row, means followed by the same uppercase letter(s) are not significantly different; within each life stage and column, means followed by the same lowercase letter(s) are not significantly different; where no letters exist, no significant differences were noted; in all cases for rows $\mathrm{df}=2,24$, for columns $\mathrm{df}=3,32$; HSD test at 0.5 .

${ }^{d}$ Two-way ANOVA results for nymphs: dose, $\mathrm{df}=3,96, F=6.5, P<0.01$; commodity, $\mathrm{df}=2,96, F=39.2, P<0.01$; dose $\times$ commodity, df $=6,96, F=2.6, P=0.02$.

Progeny production on different crops. Generally, in the untreated controls, more progeny were produced on wheat than on rice or maize, and more progeny were produced on rice than on maize. On untreated wheat, more progeny were produced by $L$. entomophila, followed by $L$. reticulatus, then by $L$. bostrychophila, $L$. decolor, and lastly, L. paeta. On maize and rice, the order of greatest to least progeny production was almost the same as on wheat for $L$. entomophila, $L$. reticulatus, $L$. bostrychophila, $L$. paeta, and L. decolor.

\section{DISCUSSION}

Our results show that methoprene reduced the numbers of adult progeny in all commodities at application rates of 5 and $10 \mathrm{ppm}$. At $1 \mathrm{ppm}$, numbers of adults were reduced on wheat and maize, but not on rice, except for L. paeta. Bucci (3) obtained the same results with higher rates of a less efficacious formulation of methoprene for L. bostrychophila, while Nayak et al. $(21,22)$ obtained results similar to ours, at $1 \mathrm{ppm}$.

TABLE 5. Number of adults and nymphs of Liposcelis decolor per vial 40 days after the introduction of 10 female parental individuals on untreated commodities $\left(0\right.$ ppm) or commodities treated with methoprene at three dose rates ${ }^{a}$

\begin{tabular}{|c|c|c|c|c|c|c|}
\hline Stage & Dose (ppm) & Wheat & Rice & Maize & $F$ value & $P$ value \\
\hline \multirow[t]{6}{*}{ Adults $^{b}$} & 0 & $67.1 \pm 4.8 \mathrm{~A} \mathrm{a}^{c}$ & $27.8 \pm 4.6$ в а & $12.9 \pm 3.3$ в а & 42.1 & $<0.01$ \\
\hline & 1 & $15.2 \pm 4.2 \mathrm{~A} \mathrm{~b}$ & $19.4 \pm 6.1 \mathrm{~A} \mathrm{a}$ & $3.1 \pm 0.7$ в $\mathrm{b}$ & 3.9 & 0.03 \\
\hline & 5 & $3.9 \pm 0.8 \mathrm{AB} \mathrm{b}$ & $5.9 \pm 0.9 \mathrm{~A} \mathrm{~b}$ & $1.0 \pm 0.9$ в $\mathrm{b}$ & 7.8 & $<0.01$ \\
\hline & 10 & $3.7 \pm 0.8 \mathrm{AB} \mathrm{b}$ & $5.0 \pm 0.8 \mathrm{~A} \mathrm{~b}$ & $1.4 \pm 0.6$ в $b$ & 6.3 & $<0.01$ \\
\hline & $F$ value & 87.2 & 8.0 & 9.9 & & \\
\hline & $P$ value & $<0.01$ & $<0.01$ & $<0.01$ & & \\
\hline \multirow[t]{6}{*}{ Nymphs $^{d}$} & 0 & $32.7 \pm 4.4 \mathrm{~A} \mathrm{a}$ & $28.3 \pm 5.7 \mathrm{AB} \mathrm{ab}$ & $14.0 \pm 1.2$ в а & 5.2 & 0.01 \\
\hline & 1 & $25.4 \pm 3.8$ в ар & $51.6 \pm 13.2 \mathrm{~A} \mathrm{a}$ & $8.5 \pm 1.8 \mathrm{c} \mathrm{b}$ & 7.3 & $<0.01$ \\
\hline & 5 & $18.4 \pm 3.9 \mathrm{~A} \mathrm{~b}$ & $27.6 \pm 5.3 \mathrm{~A} \mathrm{ab}$ & $3.7 \pm 1.3$ в $b$ & 12.1 & $<0.01$ \\
\hline & 10 & $14.7 \pm 2.3 \mathrm{~A} \mathrm{~b}$ & $16.7 \pm 2.3 \mathrm{~A} \mathrm{~b}$ & $5.6 \pm 1.0$ в & 6.9 & $<0.01$ \\
\hline & $F$ value & 4.7 & 3.6 & 11.1 & & \\
\hline & $P$ value & $<0.01$ & 0.02 & $<0.01$ & & \\
\hline
\end{tabular}

${ }^{a}$ Values are means \pm SE.

${ }^{b}$ Two-way ANOVA results for adults: dose, $\mathrm{df}=3,96, F=73.4$; commodity, $\mathrm{df}=2,96, F=33.4$; dose $\times$ commodity, $\mathrm{df}=6,96, F=$ 19.0 ; in all cases $P<0.01$.

${ }^{c}$ Within each row, means followed by the same uppercase letter(s) are not significantly different; within each life stage and column, means followed by the same lowercase letter(s) are not significantly different; where no letters exist, no significant differences were noted; in all cases for rows $\mathrm{df}=2,24$ for columns $\mathrm{df}=3,32$; HSD test at 0.5 .

${ }^{d}$ Two-way ANOVA results for nymphs: dose, $\mathrm{df}=3,96, F=6.3, P<0.01$; commodity, $\mathrm{df}=2,96, F=21.6, P<0.01$; dose $\times$ commodity, df $=6,96, F=2.7, P=0.02$. 
Our study also showed that, with some exceptions, methoprene generally did not reduce the production of nymphs in the treatments relative to the controls. One hypothesis for this observation is that nymphs might have been arrested in that stage, and were unable to mature to adults. Exposure of larvae of the Indianmeal moth, Plodia interpunctella (Hübner) (Lepidoptera: Pyralidae), to the juvenile hormone analogue hydroprene either prolonged development time or resulted in failure to molt to the adult stage (18). Normally, 40 days is sufficient for the psocid species evaluated in our study to complete their life cycle. Opit and Throne (25) found that egg-to-adult development was $<30$ days for L. reticulatus at $30^{\circ} \mathrm{C}$. Developmental times are similar for L. bostrychophila (32), L. decolor (28), L. entomophila (30), and L. paeta (31).

Nayak et al. $(21,22)$ concluded that methoprene was not effective against $L$. bostrychophila, $L$. entomophila, $L$. paeta, and L. decolor, and a survey of field populations of $L$. bostrychophila and L. entomophila indicated that this tolerance is a natural phenomenon and it is not related to resistance. Reduced efficacy of IGRs has been also recorded in the case of other stored-product insect species. For example, IGRs are not effective against Sitophilus spp. because oviposition and immature development occur inside the kernel $(8,10,11,13-15,21,27)$, and some strains of Rhyzopertha dominica (F.) (Coleoptera: Bostrychidae) have developed resistance to methoprene (5).

Methoprene did not exhibit the same efficacy in the three grains tested. Samson et al. (27) found that the efficacy of three IGRs against $R$. dominica differed between paddy rice and maize. Apparently, this trend is closely related with developmental parameters of the species tested on wheat, rice, and maize. In our test, wheat and rice were more suitable than maize was for the development of psocid populations. Opit and Throne (26) found that population growth of $L$. reticulatus and $L$. entomophila was reduced on maize, as compared with other grains such as wheat, rice, sorghum, and barley. Hence, these differences may indirectly determine efficacy of methoprene, through their effect on developmental parameters of progeny or the fecundity of parental individuals. Interactions between the substrate and the insecticide can affect both uptake and efficacy, as has been reported in studies in which insecticides were applied on different surfaces for control of psocids (6).

Previous studies have shown that methoprene applied at 1 to $5 \mathrm{ppm}$ gives complete control of $R$. dominica (4) and Oryzaephilus surinamensis (L.) (Coleoptera: Silvanidae) (9). Our results show that application rates of methoprene even greater than $10 \mathrm{ppm}$ may be also unable to completely suppress psocid populations. Nevertheless, another option would be to combine a lower application rate of methoprene with a contact insecticide. Daglish et al. (9) found that the combined use of methoprene with spinosad or chlorpyriphos-methyl was able to control several beetle species that could not be controlled by the application of either insecticide alone. Chanbang et al. (4) reported similar results for the combination of methoprene with diatomaceous earth. Additional studies would be required to determine if combination treatments would be effective for control of stored-product psocids.

\section{ACKNOWLEDGMENTS}

We thank Ann Redmon and Ngunza Kisangani for technical assistance and Wellmark International (Schaumburg, IL) for providing the methoprene sample. We also thank Manoj Nayak for his comments on an earlier version of this manuscript. Mention of trade names or commercial products in this publication is solely for the purpose of providing specific information and does not imply recommendation or endorsement by the U.S. Department of Agriculture or the University of Thessaly.

\section{REFERENCES}

1. Arthur, F. H., J. E. Throne, R. A. Simonaitis, and J. M. Zehner. 1990. Evaluation of chlorpyriphos-methyl and chlorpyriphos-methyl plus methoprene as protectants of stored corn: small bin tests. J. Econ. Entomol. 83:1114-1121.

2. Athanassiou, C. G., N. G. Kavallieratos, F. C. Tsaganou, B. J. Vayias, C. B. Dimizas, and C. T. Buchelos. 2003. Effect of grain type on the insecticidal efficacy of SilicoSec against Sitophilus oryzae (L.) (Coleoptera: Curculionidae). Crop. Prot. 22:1141-1147.

3. Bucci, R. 1994. Effects of two insect growth regulators on the booklouse Liposcelis bostrychophila. J. Stored Prod. Res. 30:157161

4. Chanbang, Y., F. H. Arthur, G. E. Wilde, and J. E. Throne. 2007. Efficacy of diatomaceous earth and methoprene, alone and in combination, against Rhyzopertha dominica (F.) (Coleoptera: Bostrychidae). J. Stored Prod. Res. 43:396-401.

5. Collins, P. J. 1998. Resistance to grain protectants and fumigants in insect pests of stored products in Australia, p. 55-57. In H. J. Banks, E. J. Wright, and K. A. Damcevski (ed.), Stored grains in Australia: Proceedings of the Australian Post-Harvest Technical Conference, Canberra, CSIRO, Canberra, Australia, 26 to 29 May 1998.

6. Collins, P. J., M. K. Nayak, and R. Kopittke. 2000. Residual efficacy of four organophosphate insecticides on concrete and galvanized steel against three liposcelid psocid species (Psocoptera: Liposcelidae) infesting stored products. J. Econ. Entomol. 93:1357-1363.

7. Daglish, G. J. 1998. Efficacy of six grain protectants applied alone or in combination against three species of Coleoptera. J. Stored Prod. Res. 34:263-268.

8. Daglish, G. J. 2008. Impact of resistance on the efficacy of binary combinations of spinosad, chlorpyriphos-methyl and $s$-methoprene against five stored-grain beetles. J. Stored Prod. Res. 44:71-76.

9. Daglish, G. J., M. Eelkema, and L. M. Harrison. 1995. Chlorpyriphos-methyl plus either methoprene or synergised phenothrin for control of Coleoptera in maize in Queensland, Australia. J. Stored Prod. Res. 31:235-241.

10. Daglish, G. J., and C. Pulvirenti. 1997. Reduced fecundity of Rhyzopertha dominica (F.) (Coleoptera: Bostrichidae) following exposure of adults to methoprene. J. Stored Prod. Res. 34:201-206.

11. Daglish, G. J., and B. E. Wallbank. 2005. Efficacy of diflubenzuron plus methoprene against Sitophilus oryzae and Rhyzopertha dominica in stored sorghum. J. Stored Prod. Res. 41:353-360.

12. Daglish, G. J., B. E. Wallbank, and M. K. Nayak. 2003. Synergized bifenthrin plus chlorpyriphos-methyl for control of beetles and psocids in sorghum in Australia. J. Econ. Entomol. 96:525-532.

13. Desmarchelier, J. M., and S. E. Allen. 1992. Diflubenzuron as a grain protectant for control of Sitophilus species. J. Stored Prod. Res. 28: 283-287.

14. Edwards, J. P., and J. E. Short. 1984. Evaluation of three compounds with insect juvenile hormone activity as grain protectants against insecticide susceptible and resistant strains of Sitophilus species (Coleoptera: Curculionidae). J. Stored Prod. Res. 20:1-15.

15. Edwards, J. P., J. E. Short, and L. Abraham. 1991. Large-scale evaluation of the insect juvenile hormone analogue fenoxycarb as a long-term protectant of stored wheat. J. Stored Prod. Res. 27:31-39.

16. Fang, L., B. Subramanyam, and F. H. Arthur. 2002. Effectiveness of spinosad on four classes of wheat against five stored product insects. J. Econ. Entomol. 95:640-650. 
17. Kučerová, Z. 2002. Weight losses of wheat grains caused by psocid infestation. Plant Prot. Sci. 38:103-107.

18. Mohandass, S., F. H. Arthur, K. Y. Zhu, and J. E. Throne. 2006. Hydroprene prolongs developmental time and increases mortality in wandering-phase Indianmeal moth (Lepidoptera: Pyralidae) larvae. $J$. Econ. Entomol. 99:1509-1519.

19. Mondal, K. A. M. S. H., and S. Parween. 2000. Insect growth regulators and their potential management of stored-product insect pests. Integr. Pest Manag. Rev. 5:255-295.

20. Nayak, M. K. 2006. Psocid and mite pests of stored commodities: small but formidable enemies, p. 1061-1073. In I. Lorini, B. Bacaltchuk, H. Beckel, D. Deckers, E. Sundfeld, J. P. dos Santos, J. D. Biagi, J. C. Celaro, L. R. D' A. Faroni, L. de O. F. Bortolini, M. R. Sartori, M. C. Elias, R. N. C. Guedes, R. G. da Fonseca, and V. M. Scussel (ed.), Proceedings of the 9th International Working Conference on Stored-Product Protection, Campinas, Sao Paulo, Brazil, 15 to 18 October 2006.

21. Nayak, M. K., P. J. Collins, and H. Pavic. 2002. Long-term effectiveness of grain protectants and structural treatments against Liposcelis decolor (Pearman) (Psocoptera: Liposcelididae), a pest of stored products. Pest Manag. Sci. 58:1223-1228.

22. Nayak, M. K., P. J. Collins, and R. S. Reid. 1998. Efficacy of grain protectants and phosphine against Liposcelis bostrychophila, L. entomophila and L. paeta (Psocoptera: Liposcelidae). J. Econ. Entomol. 91:1208-1212.

23. Nayak, M. K., G. J. Daglish, and V. S. Byrne. 2005. Effectiveness of spinosad as a grain protectant against resistant beetle and psocid pests of stored grain in Australia. J. Stored Prod. Res. 41:455-467.

24. Oberlander, H., D. L. Silhacek, E. Shaaya, and I. Ishaaya. 1997. Current status and future perspectives of the use of insect growth regulators for the control of stored product insects. J. Stored Prod. Res. 33:1-6.
25. Opit, G. P., and J. E. Throne. 2008. Population growth and development of psocid Lepinotus reticulatus at constant temperatures and relative humidities. J. Econ. Entomol. 101:605-615.

26. Opit, G. P., and J. E. Throne. 2008. Effects of diet on population growth of psocids Lepinotus reticulatus and Liposcelis entomophila. J. Econ. Entomol. 101:616-622.

27. Samson, P. R., R. J. Parker, and E. A. Hall. 1990. Efficacy of the insect growth regulators methoprene, fenoxycarb and diflubenzuron against Rhyzopertha dominica (F.) (Coleoptera: Bostrichidae) on maize and paddy rice. J. Stored Prod. Res. 26:215-221.

28. Tang, P. A., J. J. Wang, Y. Ye, H. B. Jiang, and Z. Y. Wang. 2008. Development, survival, and reproduction of the psocid Liposcelis decolor (Psocoptera: Liposcelididae) at constant temperatures. Ann. Entomol. Soc. Am. 101:1017-1025.

29. Throne, J. E., G. P. Opit, and P. W. Flinn. 2006. Seasonal distribution of psocids in stored wheat, p. 1095-1103. In I. Lorini, B. Bacaltchuk, H. Beckel, D. Deckers, E. Sundfeld, J. P. dos Santos, J. D. Biagi, J. C. Celaro, L. R. D' A. Faroni, L. de O. F. Bortolini, M. R. Sartori, M. C. Elias, R. N. C. Guedes, R. G. da Fonseca, and V. M. Scussel (ed.), Proceedings of the 9th International Working Conference on StoredProduct Protection, ABRAPOS, Campinas, Sao Paulo, Brazil, 15 to 18 October 2006.

30. Wang, J., Z. Zhao, and L. Li. 1998. Studies on bionomics of Liposcelis entomophila (Psocoptera: Liposcelididae) infesting stored products. Entomol. Sinica 5:149-158.

31. Wang, J. J., Y. Ren, X. Q. Wei, and W. Dou. 2009. Development, survival, and reproduction of the psocid Liposcelis paeta (Psocoptera: Liposcelididae) as a function of temperature. J. Econ. Entomol. 102: $1705-1713$.

32. Wang, J. J., J. H. Tsai, Z. H. Zhao, and L. S. Li. 2000. Development and reproduction of the psocid Liposcelis bostrychophila (Psocoptera: Liposcelididae) as a function of temperature. Ann. Entomol. Soc. Am. 93:261-270. 